V.M. Govorukha, O.B. Tashyrev

Zabolotny Institute of Microbiology and Virology of the NASU, 154 Zabolotnogo Str. Kyiv, 03143, Ukraine

\title{
THE REGULARITIES OF IRON COMPOUNDS TRANSFORMATION BY CITROBACTER FREUNDII MI-31.1/1
}

\begin{abstract}
The purpose of the work was to study the regularities of Fe(III) compounds reduction under the conditions of limited aeration by the strain Citrobacter freundii Ml-31.1/1, and to assess the role of Fe(III)-reducing bacteria (FRB) in iron compounds transformation in ecosystems. The following methods were used: cultivation of microorganisms under the conditions of limited aeration, colorimetric determination of biomass and Fe(III) and Fe(II) compounds concentration, the potentiometric measuring of $\mathrm{pH}$ and Eh, gas chromatography. Results: Thermodynamic calculations of microbial interaction with iron compounds were experimentally verified. The regularities of $\mathrm{Fe}(\mathrm{III})$ and $\mathrm{Fe}$ (II) compounds transformation by the model strain Citrobacter freundii Ml-31.1/1, isolated from the typical mid-latitude ecosystem-river sludge were obtained. The balance of iron compounds redistribution in cells and in the extracellular fraction was established. Conclusions: The results obtained are the basis to assume that non-specific interaction of microorganisms with iron may significantly influence transformation of iron. Thermodynamic prognosis allows to carry out targeted regulation of microbial metabolism.
\end{abstract}

Ke y w o r d s: thermodynamic prognosis, microbial Fe(III) reduction, precipitation of iron compounds, biogeochemical cycles of iron transformation.

The participation of microorganisms in the processes of iron compounds transformation is already known for about a century $[1,2]$. Although microbial iron reduction has been studied for a long time, the regularities of iron compounds transformation by microorganisms, as well as their contribution to biogeochemical cycles of iron transformation in ecosystems are still poorly understood.

It is considered that the leading role in the reduction of $\mathrm{Fe}$ (III) to $\mathrm{Fe}$ (II) belongs to dissimilatory Fe(III)-reducing bacteria. However, a limited number of microbial species (for example, Shewanella putrefaciens, Geobacter metallireducens) is known to specifically reduce Fe(III) in dissimilatory metabolism producing energy $[3,4,5]$. On the other hand, there are many microorganisms that reduce Fe(III) compound as well as oxygen, nitrate, sulfate and other terminal electron acceptors (for example, Bacillus, Clostridium, Desulfovibrio, Escherichia, Pseudomonas, etc.) [2,6].

Thermodynamic evaluation of pathways of iron compounds transformation confirms that $\mathrm{Fe}(\mathrm{III})$ may be reduced to $\mathrm{Fe}$ (II) by a wide range of microorganisms. We assume that these microorganisms can reduce $\mathrm{Fe}$ (III) compounds non-specifically, i.e, by production of exometabolites-reducing agents, by lowering of redox-potential of nutrient medium, as well as by lowpotential redox-enzymes functioning.

These organisms are widespread in natural ecosystems, and microbial reduction of $\mathrm{Fe}$ (III) to $\mathrm{Fe}$ (II) is thermodynamically feasible. So, we assume that the non-specific $\mathrm{Fe}$ (III) reduction should significantly influence the biogeochemical cycles of iron compounds transformation in ecosystems. 
Therefore, the purpose of our work was to study the regularities of $\mathrm{Fe}(\mathrm{III})$ compounds reduction under the conditions of limited aeration by the strain Citrobacter freundii Ml-31.1/1, and to assess the role of Fe(III)-reducing bacteria in iron compounds transformation in ecosystems.

Materials and methods. The regularities of microbial iron reduction were studied using a model strain Citrobacter freundii Ml-31.1/1. We isolated as the result of natural ecosystems screening for the presence of $\mathrm{Fe}$ (III)-reducing bacteria. We isolated the strain from a widespread natural ecosystem of middle latitudes - river sludge (river Grun, Synivka village, Sumy region, Ukraine). The strain reduced $\mathrm{Fe}$ (III) compounds the most effectively among the dominant strains of this ecosystem. Basing on the totality of morphological, physiological and biochemical characteristics as well as phylogenetic analysis results the strain was identified as Citrobacter freundii. The strain Citrobacter freundii Ml-31.1/1 is deposited in the collection of Department of Extremophilic Microorganisms Biology of Zabolotny Institute of Microbiology and Virology of NASU.

River sludge is a mixture of organic compounds that are degradation products of aquatic organisms. Therefore, cultivation of microorganisms was carried out in protein nutrient medium "Nutrient broth" (NB) (HiMedia Laboratories Pvt. Ltd., India), and in the NB with glucose (NB+gl) (glucose concentration was $10 \mathrm{~g} / \mathrm{l}$ ). Glucose was used as the additional carbon and energy source stimulating the functioning of low-potential redox-enzymes. The concentration $\mathrm{Fe}$ (III) citrate in the nutrient medium was $0.2 \mathrm{~g} / \mathrm{l}$ of iron cations.

Nutrient medium $(200 \mathrm{ml})$ and $3 \mathrm{ml}$ of microbial suspension in physiological solution (McFarland standard 6 $-1.8 \cdot 10^{9} \mathrm{CFU} / \mathrm{ml}$ of cell suspension) were added in flasks (volume $250 \mathrm{ml}$ ). The flasks were sealed by rubber stoppers and metal clamps. Cultivation was carried out under the conditions of limited aeration at $30^{\circ} \mathrm{C}$ during 48 hours.

Following parameters were the criteria of microbial metabolic activity. They were change of $\mathrm{pH}$ and Eh value, oxygen consumption, hydrogen and carbon dioxide synthesis by microorganisms, biomass increase, decrease of $\mathrm{Fe}(\mathrm{III})$ concentration and increase of $\mathrm{Fe}$ (II) concentration.

The $\mathrm{pH}$ and $\mathrm{Eh}$ of the culture liquid was measured by the potentiometric method with the $\mathrm{pH}$-meter-millivoltmeter " $\mathrm{pH}-150 \mathrm{MA}$ ". The measuring electrode ЭCK-10603/4 was used to determine the $\mathrm{pH}$. Redox-potential was measured using platinum measuring electrode ЭПВ-1. The silver chloride electrode ЭВЛ-1M3 was used as reference.

The gas phase composition in the flasks was determined by the standard method using a gas chromatograph ЛХМ-8-МД [7]. The chromatograph is equipped with two steel columns - first (I) for analysis of $\mathrm{H}_{2}, \mathrm{O}_{2}, \mathrm{~N}_{2}$ and $\mathrm{CH}_{4}$, second (II) - for analysis of $\mathrm{CO}_{2}$.

Detector-katharometer column parameters: $\mathrm{I}-1=3 \mathrm{~m}, \mathrm{~d}=3 \mathrm{~mm}$, with a molecular sieve $13 \mathrm{X}(\mathrm{NaX})$; II $-1=2 \mathrm{~m}, \mathrm{~d}=3 \mathrm{~mm}$, with Porapak-Q carrier. Column temperature $-+60^{\circ} \mathrm{C}$, evaporator temperature $-+75^{\circ} \mathrm{C}$, detector temperature $-+60^{\circ} \mathrm{C}$. The detector current $-50 \mathrm{~mA}$. Carrier gas - argon, the gas flow rate $-30 \mathrm{~cm}^{3} / \mathrm{min}$.

The percentage of primary gases $-\mathrm{H}_{2}, \mathrm{CO}_{2}, \mathrm{~N}_{2}$ and $\mathrm{O}_{2}-$ in the gas phase was determined by the standard procedure calculating the peak square of the gas phase components. 
The concentration of $\mathrm{Fe}(\mathrm{III})$ and $\mathrm{Fe}(\mathrm{II})$ was determined in cells and in the extracellular fraction. The concentration of dissolved and precipitated Fe(III) and $\mathrm{Fe}$ (II) compounds was also calculated in the extracellular fraction.

The contents of $\mathrm{Fe}$ (III) and $\mathrm{Fe}$ (II) was measured by colorimetric methods. The concentration of $\mathrm{Fe}(\mathrm{II})$ was determined using $o$-phenanthroline [8]. For this purpose $0.75 \mathrm{ml}$ of $0.25 \% o$-phenanthroline solution was added to $1.5 \mathrm{ml}$ of the sample. The presence of Fe(II) was indicated by the appearance of redorange color due to the interaction of $\mathrm{Fe}$ (II) compounds with $o$-phenanthroline. The measurement of $\mathrm{Fe}(\mathrm{II})$ was conducted using the photoelectric colorimeter (КФК-2MП) at $\lambda=490 \mathrm{~nm}$ and an optical path length of $0.5 \mathrm{~cm}$.

The concentration of $\mathrm{Fe}$ (III) was determined by the formation of red-colored compounds of $\mathrm{Fe}$ (III) with potassium rhodanide in acidic conditions [8]. Rhodanide $(0.25 \mathrm{ml}$ of $1.5 \mathrm{M} \mathrm{KSCN})$ and $0.75 \mathrm{ml}$ of concentrated $\mathrm{HCl}$ were added to $1.5 \mathrm{ml}$ of the sample. The presence of Fe(III) was indicated by the appearance of the red color. Concentration of Fe(II) was measured on photoelectric colorimeter (КФК-2MП) at $\lambda=490 \mathrm{~nm}$ and optical path length of $1 \mathrm{~cm}$.

The concentration of iron compounds was measured according to the following scheme. First of all, $6 \mathrm{ml}$ of culture liquid was centrifuged at $2655 \mathrm{~g}$ for 15 minutes. The supernatant was decanted and used for the measurement of dissolved iron compounds concentrations by the method described above.

The precipitate consisted of bacterial biomass and precipitated iron compounds. It was suspended in the same volume $(6 \mathrm{ml})$ of citric acid solution $(3 \mathrm{~g} / \mathrm{l})$. Citric acid solution of was used as the chelating compound to transform the precipitated iron compound into dissolved form. which is available for the colorimetric measuring. The obtained solution was centrifuged at $2655 \mathrm{~g}$ for 15 minutes again. The supernatant was decanted and used to determine the concentration of the precipitated iron compounds.

The precipitate consisting of bacterial biomass was suspended in $6 \mathrm{ml}$ of physiological solution to measure its optical density. Optical density of the cell suspension was measure by photoelectric colorimeter (КФК-2MП) at $\lambda=540 \mathrm{~nm}$ in $0.5 \mathrm{~cm}$ cuvette. Biomass growth was estimated by increase of its concentration in the medium. For this purpose optical density of biomass suspension was recalculated to the concentration of biomass according to the calibration graph.

The cell suspension was centrifuged one more time at $2655 \mathrm{~g}$ for 15 minutes. The supernatant was decanted. The precipitated biomass of microorganisms was used to determine the concentration of iron compounds in cells. The precipitate was suspended in $6 \mathrm{ml}$ of $10 \% \mathrm{HCl}$. Microbial cells were lysed in strongly acidic conditions at $\mathrm{pH}=1.0$. Iron compounds became available for measurement. The color of $\mathrm{Fe}(\mathrm{II})$ and $o$-phenanthroline complex develops slowly and is weakly expressed at $\mathrm{pH}<2.0$ [8]. Therefore, the obtained acidic solution was neutralized by adding dry $\mathrm{Na}_{2} \mathrm{CO}_{3}$ to accurately measure the concentration of $\mathrm{Fe}(\mathrm{II})$ compounds in the cell fraction.

Results and discussion. Only a limited number of microorganisms (for example, Shewanella putrefaciens, Geobacter metallireducens) were thought to reduce $\mathrm{Fe}(\mathrm{III})$ compounds and to use it as a terminal electron acceptor in dissimilatory metabolism $[3,4]$.

Thermodynamic evaluation of iron compounds transformation pathways showed that microorganisms may reduce $\mathrm{Fe}(\mathrm{III})$ to $\mathrm{Fe}(\mathrm{II})$, as well as mobilize 
and immobilize iron compounds. The transformation of iron compounds is determined by the values of $\mathrm{pH}$ and redox-potential, that are influenced by microorganisms. The fields of iron thermodynamic stability were designed by us according to Pourbaix equations [9].

$\mathrm{Fe}$ (III)-reducing bacteria were shown to be widespread in natural ecosystems according to our previous screening. These ecosystems differ in geographical location (Antarctic, Arctic, the Dead and the Black Sea, South America (Ecuador), mid-latitudes (Ukraine, Abkhazia)) and in a range of extreme factors affecting microorganisms (organic and inorganic xenobiotics, temperature, light conditions, etc.) [10].

Iron compounds are present in ecosystems at a concentration from several milligrams to grams per $1 \mathrm{~kg}$ of soil [11]. The number $\mathrm{Fe}(\mathrm{III})$-reducing bacteria, according to our researches, ranges from $1.1 \cdot 10^{2}$ to $2.8 \cdot 10^{7} \mathrm{cell} / \mathrm{s} / \mathrm{g}$ of absolutely dry sample [12]. Therefore, microorganisms capable to reduce $\mathrm{Fe}$ (III) to $\mathrm{Fe}$ (II) can be assumed to play an important role in the biogeochemical cycles of iron compounds transformation in ecosystems.

Microbial iron reduction efficiency depends on the difference of potentials between electron donor and acceptor systems. Acceptor system potential, i.e. $\mathrm{Fe}$ (III) compounds, doesn't change. Therefore, the efficiency of microbial iron reduction can be increased by changing the potential of donor system $[9,13]$. In this connection, to study the regularities of iron compounds transformation model strain Citrobacter freundii Ml-31.1/1 was inoculated in two variants of the liquid medium. The first one was a protein medium (nutrient broth $-\mathrm{NB}$ ). The second one was a protein medium with glucose at the concentration of $10 \mathrm{~g} / \mathrm{l}$. Glucose was used as an additional low-potential electron donor for microorganisms.

Comparison of microbial growth parameters indicated that the presence of glucose in protein culture medium increased the activity of the strain growth (Fig. 1).

This is manifested in the biomass increase. Culture reaches the stationary growth phase after 5 hours of cultivation in protein culture medium, as well as in the medium with glucose. However, the optical density at this point is 1.4 times higher in the medium with glucose. Decrease of $\mathrm{pH}$ and redox-potential of the medium was proportional to the growth of biomass during 5 hours of cultivation. The $\mathrm{pH}$ of the protein medium decreased to a minimum value of 6.9 , and than remained within 7.0-7.2. The $\mathrm{pH}$ of the medium with glucose decreased to 6.4 in 5 hours of growth, and further - to 5.3 gradually over the
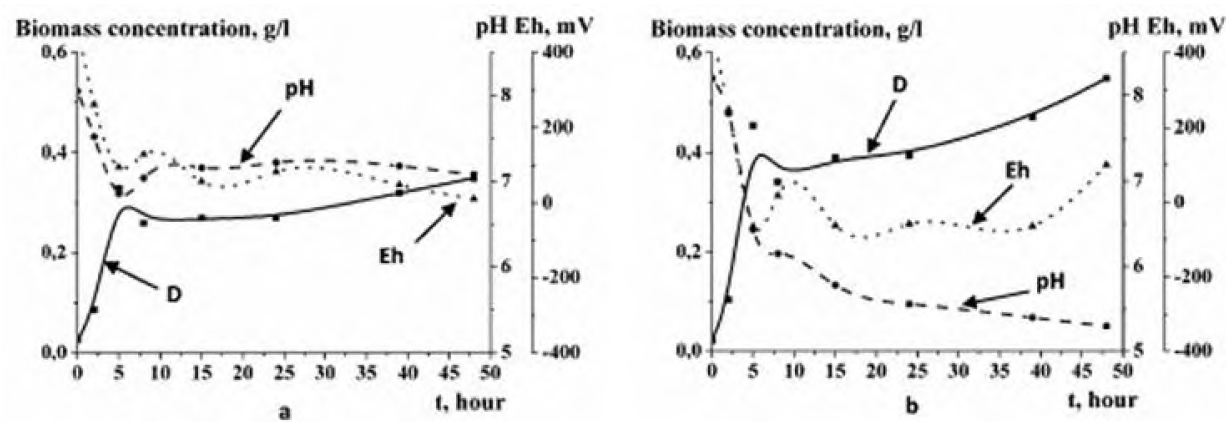

Fig. 1. Dynamics of changes in growth metabolic parameters of the strain Citrobacter freundii $\mathrm{MI-31.1/1:} \mathbf{a}-$ in protein medium $(\mathrm{NB}) ; \mathbf{b}-$ in protein medium with glucose $(\mathrm{NB}+\mathrm{gl})$ 
next 43 hours. The redox-potential of the medium with glucose was decreased from $+450 \mathrm{mV}$ to $-65 \mathrm{mV}$, and of the protein medium - only to $+95 \mathrm{mV}$. Consequently, during the strain growth redox-potential of the medium with glucose decreased to $160 \mathrm{mV}$ lower than of the protein medium.

Oxygen consumption occurred proportionally to the biomass growth in the protein medium (Fig. 2). The concentration of $\mathrm{O}_{2}$ in the gas phase decreased from $21 \%$ to $13.9 \%$ during 8 hours of growth. After microorganisms reached the stationary growth phase the rate of its use was significantly decreased. At the same time the concentration of $\mathrm{O}_{2}$ on glucose medium was decreased up to $11.3 \%$. After 15 hours of microbial growth the concentration of $\mathrm{O}_{2}$ on glucose medium was $4 \%$.

The concentration of carbon dioxide after 8 hours of cultivation in the medium with glucose was 1.8 times higher than in the protein medium. The maximum concentration of $\mathrm{CO}_{2}$ in the protein medium was $7.6 \%$ after 48 hours of the strain growth. In the medium with glucose maximum concentration of carbon dioxide $(23.8 \%$ ) was noted after 39 hours.

The maximum hydrogen concentration after 8 hours of cultivation in protein medium was $1.3 \%$, that is 5 times lower than in the medium with glucose. Maximum concentration of $\mathrm{H}_{2}$ on the medium with glucose was after 15 hours of cultivation $(21.6 \%$ ) and then remained within $15.7-14.5 \%$. It is 18 times higher than for the protein medium.

Thermodynamic evaluation allows to prognose the pathways of iron compounds transformation by microorganisms. The data obtained suggest that the strain can quickly and effectively reduce Fe(III) to Fe(II) $[9,10]$. This is facilitated by low value of the redox-potential of culture liquid, intensive decrease of oxygen concentration in the gas phase that may inhibit $\mathrm{Fe}$ (III) reduction as the competitive terminal electron acceptor [13]. Active hydrogen synthesis may indicate the functioning of low potential redox-enzymes that contribute to the effective reduction of $\mathrm{Fe}$ (III) compounds.

Comparison of metabolic parameters of the strain growth gives reason to suppose that the efficiency of $\mathrm{Fe}$ (III) reduction by microorganisms will be higher on the medium with glucose. This is evidenced by the following: the redox-potential of the medium with glucose was $160 \mathrm{mV}$ lower than that of the protein medium, concentration of $\mathrm{O}_{2}$ after 15 hours of growth was 2.8 times lower and $\mathrm{H}_{2}$ concentration was 19.1 times higher.
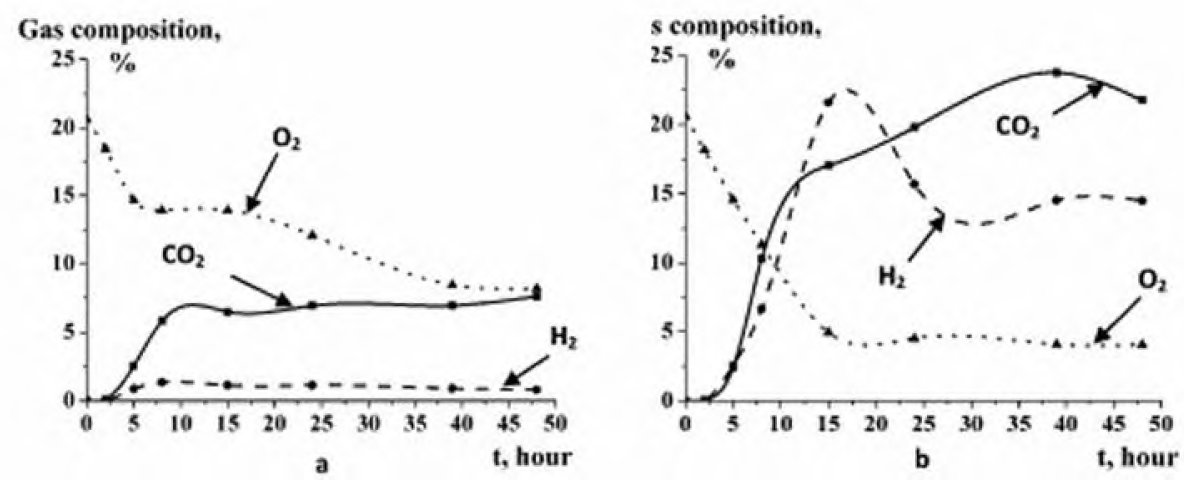

Fig. 2. Dynamics of changes in the concentration of $\mathrm{O}_{2}, \mathrm{H}_{2}, \mathrm{CO}_{2}$ during the growth of the strain Citrobacter freundii Ml-31.1/1: a - in protein medium (NB); $\mathbf{b}$ - in protein medium with glucose $(\mathrm{NB}+\mathrm{gl})$ 
We can prognose $\mathrm{Fe}(\mathrm{III})$ reduction, as well as the effectiveness of iron compounds precipitation. Basing on thermodynamic calculations the efficiency of iron precipitation on the protein medium may be higher than on the medium with glucose.

Ions of $\mathrm{Fe}^{3+}$ are not stable at the $\mathrm{pH}$ above 1.6 , and $\mathrm{Fe}^{2+}$ ions - at the $\mathrm{pH}$ above 6.6 [9]. The $\mathrm{pH}$ values of the protein medium did not fall below 6.9. So it is likely that $\mathrm{Fe}$ (III) and $\mathrm{Fe}$ (II) may precipitate if microorganisms degrade the chelating compound - citrate. At the same time, organic acids are often degradation products of glucose. They may chelate iron and keep it in solution in stable form.

Furthermore, $\mathrm{CO}_{2}$ concentration increasing in the protein medium at the $\mathrm{pH}$ values close to neutral promotes the formation of insoluble iron carbonate $\left(\mathrm{FeCO}_{3}\right)$. Despite the fact that $\mathrm{CO}_{2}$ concentration in the medium with glucose was by 3.1 times higher than in the protein medium its $\mathrm{pH}$ was significantly lower (up to 5.3). Formation of insoluble iron carbonate is impossible in acidic conditions.

Formation of sulfide during the degradation of sulfur containing amino acids by microorganisms is another factor contributing to the precipitation of iron compounds. Well-soluble form of sulfide - sulfhydryl anion (HS ${ }^{-}$- dominates at the $\mathrm{pH}$ close to neutral, as it is in the protein medium. Consequently, HS precipitates $\mathrm{Fe}(\mathrm{II})$ compounds in the form of FeS. Additionally, sulfhydryl group reduces $\mathrm{Fe}(\mathrm{III})$ to $\mathrm{Fe}(\mathrm{II})$ and then forms an insoluble iron sulfide (FeS). At the same time, microorganisms acidified the medium with glucose. Under such conditions, the $\mathrm{H} 2 \mathrm{~S}$ form is predominant. Hydrogen sulfide is gas that has low solubility in water. That is why iron sulfide is not formed [14].

Obtained results of the strain Citrobacter freundii Ml-31.1/1 interaction with Fe(III) confirm our thermodynamic calculations [10]. Microorganisms reduced $\mathrm{Fe}(\mathrm{III})$ to $\mathrm{Fe}(\mathrm{II})$, precipitated iron compounds and accumulated them in cells.

As expected, Fe(III) reduction efficiency was twice higher in the medium with glucose than in the protein medium. The effectiveness of $\mathrm{Fe}$ (III) and $\mathrm{Fe}$ (II) precipitation was by 6.1 times higher in the protein medium. The efficiency of iron compounds accumulation was by 3.4 times higher in the protein medium too.

It is known that microorganisms can dissimilatory reduce $\mathrm{Fe}(\mathrm{III})$ by iron specific reductases with energy obtaining (for example, Shewanella putrefaciens, Geobacter metallireducens $[3,4,5])$. In this case, iron reduction correlates with biomass increase, that is its reduction occurs in logarithmic growth phase. This process is carried out by enzymes specialized, namely specific, for $\mathrm{Fe}(\mathrm{III})$. We call this type of $\mathrm{Fe}(\mathrm{III})$ reduction as specific iron reduction.

Another way is to reduce Fe(III) in late logarithmic and stationary growth phases, and presence of Fe(III) doesn't increase biomass yield. In this case, iron reduction may occur due to non-specific redox-enzymes as well as exometabolites-reducing agents (for example, cysteine). This type of $\mathrm{Fe}(\mathrm{III})$ reduction we call non-specific iron reduction.

Comparison of metabolic parameters of the strain growth gives reason to suppose that it reduced $\mathrm{Fe}$ (III) to Fe(II) non-specifically. Active reduction of $\mathrm{Fe}$ (III) began after 2 hours of microbial growth. Intensive Fe(III) reduction occurred in the late logarithmic growth phase, and also continued in early station- 
ary growth phase in the medium with glucose (Fig. 3). This may indicate nonspecific $\mathrm{Fe}$ (III) reduction due to the accumulation of exometabolites-reducing agents in the culture medium.

The efficiency of iron compounds precipitation was higher in the protein medium than in the medium with glucose. The most intensive Fe(III) compounds precipitation was observed when microorganisms reached the stationary growth phase after 10 hours of growth. The most intensive precipitation of insoluble Fe(II) compounds was noted after 15 hours of growth (Fig. 4).

The efficiency of iron compounds accumulation in cells was also higher in the protein medium. The rate of their accumulation does not correlate with the biomass increase. We assume that the accumulation of iron can be attributed to its sorption by dead cells. Substrate concentration in the protein medium is lower than in the protein medium with glucose, where glucose is an additional source of carbon and energy. Since microorganisms in the protein medium are limited in the substrate, the cell death and biomass sorption of iron compounds may occur more intensively. Fig. 5 illustrates the concentration of iron compounds absorbed by microbial cells.

The efficiency of Fe(III) reduction to Fe(II) twice increased when glucose was used as the additional electron donor. Concentration of Fe(II) was $89 \mathrm{mg} / \mathrm{l}$

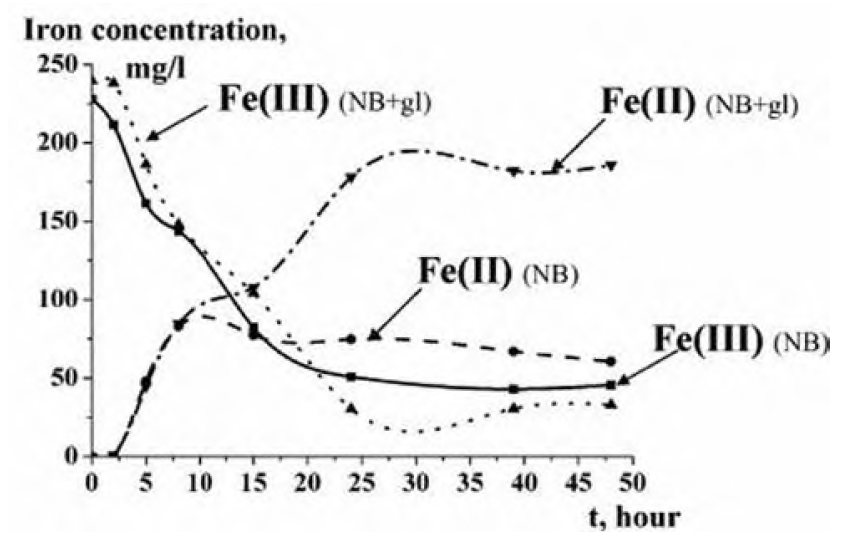

Fig. 3. Dynamics of changes in the concentration of dissolved Fe(III) and Fe(II) compounds during the growth of the strain Citrobacter freundii MI-31.1/1 in protein medium (NB) and in protein medium with glucose (NB+gl)

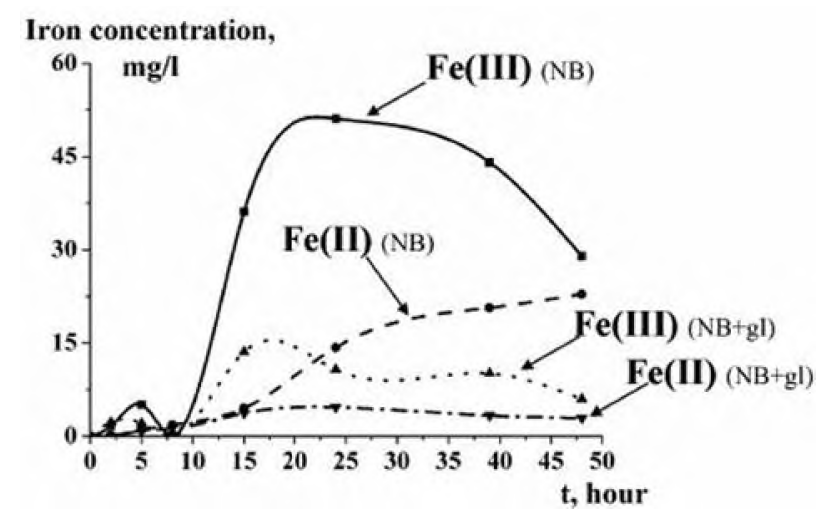

Fig. 4. Dynamics of changes in the concentration of precipitated Fe(III) and Fe(II) compounds during the growth of the strain Citrobacter freundii MI-31.1/1 in protein medium (NB) and in protein medium with glucose $(\mathrm{NB}+\mathrm{gl})$ 


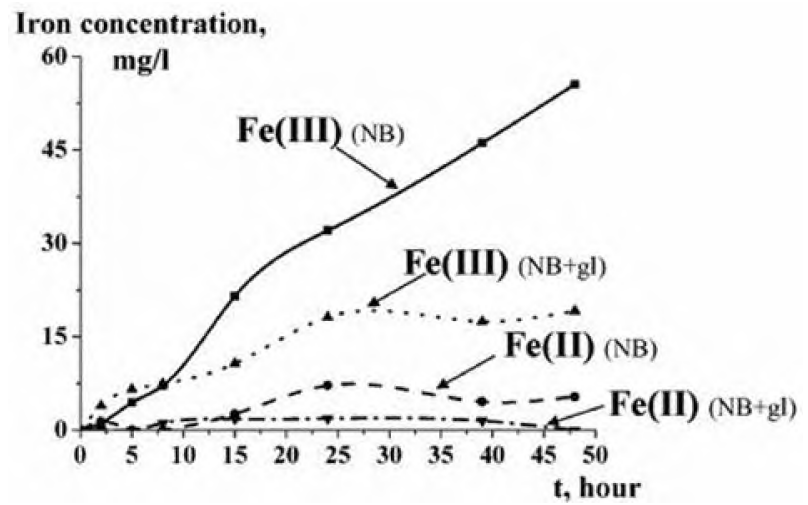

Fig. 5. Regularities of $\mathrm{Fe}$ (III) and Fe(II) compounds accumulation by cells of the strain Citrobacter freundii MI-31.1/1 in protein medium (NB) and in protein medium with glucose $(\mathbf{N B}+\mathbf{g l})$

in the protein medium after 48 hours of the strain growth, and $188 \mathrm{mg} / \mathrm{l}$ in the medium with glucose.

The balance of iron compounds redistribution in cells and the extracellular fraction after 48 hours of growth is shown on Fig. 6.

The efficiency of $\mathrm{Fe}$ (III) reduction to Fe(II) by Citrobacter freundii Ml$31.1 / 1$ was 2 times higher in the medium with glucose than in the protein medium. The efficiency of $\mathrm{Fe}$ (III) and Fe(II) precipitation in the medium with glucose was by 5 and by 8 times lower respectively. The efficiency of Fe(III) and $\mathrm{Fe}$ (II) accumulation was also 3 times lower in the medium with glucose.

Thus, we obtained the regularities of $\mathrm{Fe}$ (III) and $\mathrm{Fe}$ (II) compounds transformation by the model strain Citrobacter freundii Ml-31.1/1, isolated
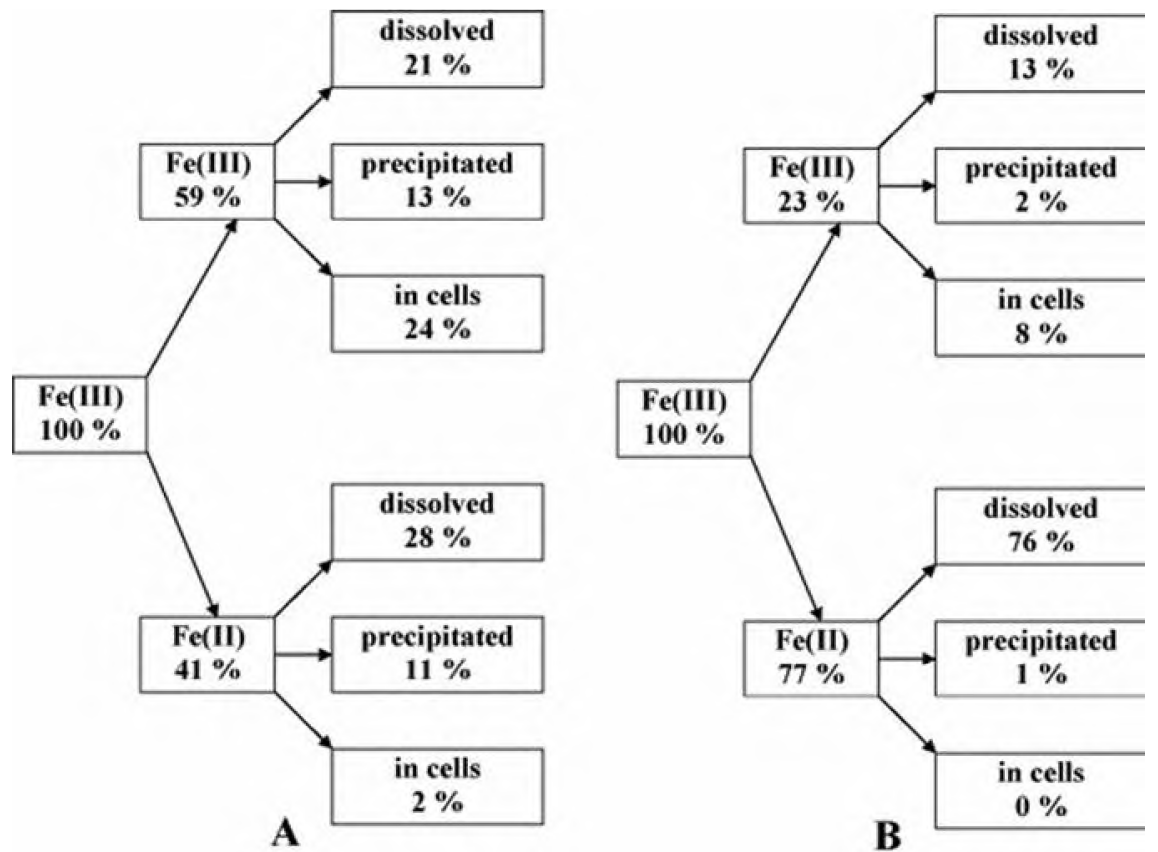

Fig. 6. The balance of redistribution of precipitated and dissolved iron compounds in cells and the extracellular fraction by the strain Citrobacter freundii MI-31.1/1: a - in protein medium in protein medium (NB) and in protein medium with glucose (NB); b - in protein medium with glucose in protein medium (NB) and in protein medium with glucose $(\mathrm{NB}+\mathrm{gl})$ 
from the typical mid-latitude ecosystem - river sludge. Thermodynamic calculations of microbial interaction with iron compounds were experimentally verified. It was shown that the reduction of $\mathrm{Fe}$ (III) to $\mathrm{Fe}$ (II) by microorganisms occurs non-specifically in late logarithmic and early stationary growth phase. It is demonstrated that efficiency of $\mathrm{Fe}$ (III)-reduction increased in the presence of low-potential electron donor. The efficiency of $\mathrm{Fe}$ (III) and $\mathrm{Fe}$ (II) compounds precipitation increased at the $\mathrm{pH}$ value close to neutral, and when carbon dioxide and sulfhydryl groups were accumulated.

\section{Conclusions.}

The results obtained are the basis to assume that non-specific interaction of microorganisms with iron may significantly influence transformation of iron.

Thermodynamic prognosis allows to carry out targeted regulation of microbial metabolism. It makes possible to prognose and control the intensity and efficiency of iron compounds transformation by microorganisms.

\section{B.М. Говоруха, О.Б. Таиирев}

Інститут мікробіологіӥ і вірусологї ім. Д.К. Заболотного НАН Украӥни, вул. Заболотного, 154, Киёв, 03143, Украйна

\section{ЗАКОНОМІРНОСТІ ТРАНСФОРМАЦІЇ СПОЛУК ЗАЛІЗА CITROBАCТЕR FREUNDII MI-31.1/1}

$\mathrm{P}$ e 3 ю $\mathrm{M}$ e

Метою роботи було дослідження закономірностей відновлення сполук $\mathrm{Fe}(\mathrm{III})$ в умовах обмеженої аерації штамом Citrobacter freundii M1-31.1/1, а також оцінка ролі залізовідновлювальних бактерій у трансформації сполук заліза в екосистемах. Були використані наступні методи: культивування мікроорганізмів в умовах обмеженої аерації, колориметричне визначення біомаси і концентрації сполук $\mathrm{Fe}(\mathrm{III})$ і $\mathrm{Fe}(\mathrm{II})$, потенціометричне вимірювання $\mathrm{pH}$ i Eh, газова хроматографія. Результати. Експериментально підтверджено термодинамічні розрахунки взаємодії мікроорганізмів зі сполуками заліза. Отримано закономірності трансформації сполук Fe(III) і Fe(II) модельним штамом Citrobacter freundii Ml-31.1/1, виділеним із типової екосистеми середніх широт України - річкового мулу. Встановлено баланс перерозподілу сполук заліза у клітинах, а також розчинених і осаджених Fe(III) i Fe(II) у позаклітинній фракції. Висновки. Отримані результати дозволяють припускати, що неспецифічна взаємодія мікроорганізмів із залізом може суттєво впливати на трансформацію сполук заліза. Термодинамічне прогнозування дозволяє здійснювати спрямовану регуляцію мікробного метаболізму.

К л ю ч о в і с л о в а: термодинамічний прогно3, мікробне відновлення $\mathrm{Fe}(\mathrm{III})$, осадження сполук заліза, біогеохімічні цикли трансформації заліза.

B.M. Говоруха, A.Б. Таиирев

Институт микробиологии и вирусологии им. Д.К. Заболотного НАН Украины, ул. Заболотного, 154, Киев, 03143, Украина

\section{ЗАКОНОМЕРНОСТИ ТРАНСФОРМАЦИИ СОЕДИНЕНИЙ ЖЕЛЕЗА CITROBACTER FREUNDII MI-31.1/1}




$$
\text { Р е } 3 \text { ю м е }
$$

Целью работы было исследование закономерностей восстановления соединений $\mathrm{Fe}(\mathrm{III})$ в условиях ограниченной аэрации штаммом Citrobacter freundii M1-31.1/1, a также оценка роли железовосстанавливающих бактерий в трансформации соединений железа в экосистемах. Были использованы следующие методы: культивирование микроорганизмов в условиях ограниченной аэрации, колориметрическое определение биомассы и концентрации соединений Fe(III) и Fe(II), потенциометрическое измерение $\mathrm{pH}$ и Eh, газовая хроматография. Результаты. Экспериментально подтверждены термодинамические расчеты взаимодействия микроорганизмов с соединениями железа. Получены закономерности трансформации соединений $\mathrm{Fe}(\mathrm{III})$ и Fe(II) модельным штаммом Citrobacter freundii Ml-31.1/1, выделенным из типовой экосистемы средних широт Украины - речного ила. Установлен баланс перераспределения соединений железа в клетках, а также растворенных и осажденных $\mathrm{Fe}$ (III) и $\mathrm{Fe}(\mathrm{II})$ во внеклеточной фракции. Выводы. Полученные результаты дают основания предполагать, что неспецифическое взаимодействие микроорганизмов с железом может существенно влиять на трансформацию соединений железа. Термодинамическое прогнозирование позволяет осушествлять направленную регуляцию микробного метаболизма.

К л ю ч е в ы е с л о в а: термодинамический прогноз, микробное восстановление $\mathrm{Fe}$ (III), осаждение соединений железа, биогеохимические циклы трансформации железа.

1. Slobodkin A.I. Thermophilic iron-reducing prokaryotes. Dissertation, INMI RAN. Moscow, Russia, 2008.

2. Lovley D.R. Organic matter mineralization with the reduction of ferric iron: a review. Geomicrobiology Journal. 1987; 5 (3/4): 375 - 99.

3. Lovley D.R. Dissimilatory Fe(III) and Mn(IV) reduction. Microbiological reviews. 1991; 55 (2): $259-87$.

4. Lovley D.R. Dissimilatory metal reduction. Annu. Rev. Microbiol. 1993; 47: 263 - 90.

5. Lovley D.R. Dissimilatory metal reduction: from early life to bioremediation. ASM News. 2002; 68 (5): $231-37$.

6. Slobodkin A.I. Thermophilic Microbial Metal Reduction. Microbiology. 2005; 74 (5): $501-14$.

7. Drugov Ju.S., Berezkin V.G. Gas chromatographic analysis of polluted air. M.: Himija, 1981. $-256 \mathrm{p}$.

8. Sendel E. Colorimetric methods of trace metals determination. M.: Mir. 1964. $-899 \mathrm{p}$.

9. Spravochnik himika / Pod red. B.P. Nikol'skogo. T. 3. - Moskva; Leningrad: Himija, 1965. $-1008 \mathrm{p}$.

10. Govorukha V., Tashyrev $O$. Thermodynamic prognosis for assessing the role of Fe(III)reducing bacteria in biegeochemical cycles of iron and carbon. Ecological Engineering and Environment Protection. 2014; 3 - 4: 45 - 54.

11. Becker M., Asch F. Iron toxity in rice-conditions and management concepts. J. Plant Nutr. Soil Sci. 2005; 168: $558-73$.

12. Govorukha V.M., Havrylyuk O.A., Tashyrev O.B. Regularities of quantitative distribution for Fe(III)-reducing bacteria in natural ecosystems. Biotechnologia Acta. 2015; 8 (3): $123-28$. 
13. Shlegel G. General microbiology. M.: Mir. 1987. - 567 p.

14. Garrels R.M., Krajst Ch.L. Solutions, minerals, balance: per. S. angl. Vitovskaja I.V. M.: Mir, 1968. -368 p.

Отримано 24.09.2015 